\title{
Uji Efek Pemberian Ekstrak Metanol Daun Beluntas (Pluchea Indica $L$ ) terhadap Kadar Glukosa dan Trigliserida Darah Mencit (Mus Musculus) yang Diinduksi Sukrosa
}

\author{
Tendri Ayu Putri ${ }^{1}$, Aceng Ruyani ${ }^{2}$, Enny Nugraheni ${ }^{1}$ \\ ${ }^{1}$ Program Studi Kedokteran Fakultas Kedokteran dan IImu Kesehatan Universitas Bengkulu, \\ ${ }^{2}$ Program Pascasarjana (S2) Pendidikan IPA Universitas Bengkulu, \\ ${ }^{3}$ Departemen Mikrobiologi Fakultas Kedokteran dan IImu Kesehatan Universitas Bengkulu.
}

\begin{abstract}
ABSTRAK
Latar Belakang: Daun $P$. indica sering digunakan sebagai obat tradisional, tetapi pemanfaatan daun $P$. indica sebagai antidiabetes pada masyarakat masih jarang dilakukan. Daun $P$. indica diidentifkasi memiliki caffeoylquinic acid aktif yang berfungsi menghambat $\alpha$-glukosidase dan bertindak sebagai agen antihiperglikemia untuk menurunkan kadar glukosa. Diabetes berhubungan dengan peningkatan trigliserida darah. Penelitian ini dilakukan untuk menilai efek pemberian ekstrak metanol daun $P$. indica terhadap kadar glukosa dan trigliserida darah $M$. musculus yang diinduksi sukrosa.
\end{abstract}

Metode: Penelitian ini menggunakan 25 ekor M. musculus yang diinduksi sukrosa $10 \%$ selama 20 hari kemudian pada hari ke $21 \mathrm{M}$. musculus dibagi menjadi 5 kelompok, yaitu kontrol negatif tanpa perlakuan, kontrol positif dengan pemberian akarbose, dan kelompok perlakuan dengan pemberian ekstrak daun $P$. indica $0.3,0,6$, dan 0,9 $\mathrm{mg} / 20 \mathrm{gBB}$. Pengukuran kadar glukosa dan trigliserida dilakukan sebelum induksi sukrosa, sebelum perlakuan, menit ke 15, 30, dan 60 setelah perlakuan.

Hasil: Setelah 20 hari induksi sukrosa M. musculus mengalami diabetes yang diikuti dengan peningkatan kadar trigliserida. Terjadi penurunan kadar glukosa sebesar $13.93 \%$ pada kelompok M. musculus yang diberi akarbose, kelompok dengan ekstrak daun $P$. indica $0.3 \mathrm{mg} / 20 \mathrm{gBB}$ sebesar $9.37 \%$, kelompok dengan ekstrak daun $P$. indica 0,6 $\mathrm{mg} / 20 \mathrm{gBB} 18,65 \%$, dan kelompok dengan ekstrak daun $P$. indica $0,9 \mathrm{mg} / 20 \mathrm{gBB}$ sebesar $37.17 \%$. Penurunan kadar trigliserida terjadi pada seluruh kelompok pemberian ekstrak daun $P$. indica akan tetapi hanya kelompok perlakuan dengan ekstrak daun $P$. indica 0,9 $\mathrm{mg} / 20 \mathrm{gBB}$ saja yang dapat menurunkan kadar trigliserida secara signifikan $(p<0.05)$ dengan penurunan sebesar $15.83 \%$.

Kesimpulan: Penelitian ini menunjukkan pemberian ekstrak metanol daun $P$. indica 0,9 $\mathrm{mg} / 20 \mathrm{gBB}$ dapat menurunkan kadar glukosa dan trigliserida darah $M$. musculus yang diinduksi sukrosa.

Kata Kunci: Daun P. indica, diabetes, kadar glukosa, kadar trigliserida.

\section{The Effect of Pluchea Indica L Leaf Extracts on Blood Glucose and Triglyceride Levels of Sucrose Induced Mice (Mus Musculus)}

\begin{abstract}
Background: The leaves of $P$. indica often used as a traditional medicine, but the utilization of $P$. indica leaf as an antidiabetic on society still Rarely. $P$. indica leaf have active caffeoylquinic acid whitch can inhibit $\alpha$-glucosidase and is acting as an agent for review antihyperglicemic to lower glucose levels. Diabetes is associated with elevated triglycerides. This research aim to assess the effect of Pluchea indica leaf extracts on blood glucose and triglyceride levels of sucrose induced mice.

Methods: This research used 25 male Swiss Webster mice (M. musculus) that induced a $10 \%$ sucrose for 20 days and then on day $21 \mathrm{M}$. musculus divided into 5 groups, negative control group, positive control group with acarbose, and treatment group with
\end{abstract}


leaf extract $P$. indica $0.3,0.6$, and $0.9 \mathrm{mg} / 20 \mathrm{gBW}$. Measurement of Glucose and triglyceride levels do before sucrose induction, before treatment, at 15, 30, and 60 minutes after treatment.

Results: After 20 days of sucrose induction, M. musculus have diabetes that was followed with elevated triglyceride levels. Positive group with acarbose can reducing levels of glucose by $13.93 \%$, treatment group with $P$. indica leaf extract $0.3 \mathrm{mg} / 20 \mathrm{gBW}$ by $9.37 \%$, the $P$. indica leaf extract $0.6 \mathrm{mg} / 20 \mathrm{gBW} 18.65 \%$, and the group $P$. indica leaf extract $0.9 \mathrm{mg} / 20 \mathrm{gBW}$ amounted to $37.17 \%$. There was a decrease in triglyceride levels at whole group with $P$. indica leaf extract but only treatment group with $P$. indica leaf extract $0.9 \mathrm{mg} / 20 \mathrm{gBB}$ can lowering triglyceride levels significantly $(\mathrm{p}<0.05)$ with a decrease of $15,83 \%$.

Conclusions: $P$. indica extract at a dose $0,9 \mathrm{mg} / 20 \mathrm{gBW}$ had significant effect on decreasing glucose and triglyceride levels of mice that were induced by sucrose.

Keywords: $P$. indica leaf, diabetic, glucose levels, triglyceride levels.

\section{PENDAHULUAN}

Diabetes melitus (DM) merupakan suatu kelompok penyakit metabolik dengan karakteristik hiperglikemia yang terjadi karena kelainan sekresi insulin, kerja insulin, atau kedua-duanya ${ }^{1}$ Pada tahun 2015 terdapat sekitar 10 juta penduduk Indonesia yang mengalami diabetes. Hal ini menjadikan Indonesia berada pada negara ketujuh terbesar di dunia yang mengalami diabetes. Bahkan IDF memprediksi hal ini akan terus meningkat pada tahun 2040 menjadi sekitar 16,2 juta penduduk Indonesia dengan diabetes. ${ }^{2}$ Diabetes tipe 2 merupakan diabetes dengan persentase terbesar dibanding diabetes jenis lain. $\mathrm{Di}$ Indonesia terdapat $90 \%$ penderita diabetes tipe 2 dibandingkan dengan diabetes jenis lain (Infodatin diabetes, 2014). Proporsi penderita diabetes melitus di Bengkulu sebanyak 11.243 orang dan terdapat sekitar 1.249 orang yang belum pernah didiagnosis diabetes melitus tetapi dalam 1 bulan terakhir mengalami gejala sering lapar, sering haus, sering buang air kecil dengan jumlah banyak dan penurunan berat badan. $^{3}$

Diabetes melitus berhubungan erat dengan peningkatan trigliserida darah. Kadar glukosa darah yang tinggi dapat mempercepat pembentukan trigliserida dalam hati. ${ }^{4}$ Peningkatan kadar trigliserida didalam darah dapat menyebabkan komplikasi diabetes berupa meningkatnya risiko penyakit jantung dan stroke akibat atherosklerosis. Atherosklerosis dapat terjadi pada pasien penderita diabetes melitus dengan peningkatan kadar glukosa darah kronik dan pada keadaan hipertrigliseridemia. ${ }^{5}$

$\begin{array}{rrr}\text { Tanaman } & \text { herbal } & \text { biasanya } \\ \text { digunakan } & \text { sebagai } & \text { agen }\end{array}$
antihiperglikemia karena terdiri senyawa fitokimia yang bertindak sebagai antioksidan. Senyawa bioaktif dari tanaman herbal juga dapat menjadi agen antidiabetes apabila tanaman tersebut mengandung komponen anti hiperglikemik dan antioksidan. ${ }^{6}$ Penelitian 
mengenai identifikasi enzim $\alpha$ glukosidase pada Pluchea indica atau tanaman beluntas dengan menggunakan kromatografi berhasil mengisolasi caffeoylquinic acid aktif yang berfungsi menghambat $\alpha$-glukosidase atau sebagai agen antihiperglikemia. ${ }^{7}$ Enzim $\alpha$ glukosidase merupakan enzim yang berperan untuk mengkonversi karbohidrat menjadi glukosa. Melalui penghambatan kerja enzim $\alpha$ glukosidase, kadar glukosa dalam darah dapat dikembalikan dalam batas normal. ${ }^{8}$ Studi fraksinasi fitokimia juga mengungkapkan bahwa ekstrak tanaman yang diperoleh dari genus Pluchea terdiri dari asam fenolik, flavonoid, tanin, monoterpen, triterpenoid, eudesmane jenis seskuiterpenoid, chalcones, phenylpropanoid, benzenoid, glikosida logan, dan steroid. ${ }^{9}$ Daun beluntas sering digunakan sebagai obat tradisional karena mudah ditemukan serta dikenal berkhasiat dalam mengobati berbagai penyakit. Beberapa kegunaan daun beluntas dimanfaatkan masyarakat sebagai penambah nafsu makan, antidiaphoretik, antipiretik, pelancar pencernaan, deodorant, antibakteria, antidiare, antitusif, dan emollient. Akan tetapi pemanfaatan daun beluntas sebagai antidiabetes pada masyarakat masih jarang dilakukan. ${ }^{10}$ Berdasarkan uraian di atas, penulis ingin mengetahui efek pemberian ekstrak metanol daun beluntas terhadap kadar glukosa dan trigliserida darah pada mencit yang diinduksi sukrosa.

\section{METODE}

Penelitian ini adalah penelitian eksperimental dengan rancangan Pre Test Post Test Control Group Design. Penelitian ini menggunakan dua puluh lima ekor mencit (Mus musculus) galur Swiss Webster berumur 6-8 minggu dengan berat badan 25 - 35 gram yang sebelumnya diadaptasikan selama 1 minggu sebelum diberikan perlakuan. Selama masa adaptasi, hewan coba diberikan diet standar. Mencit kemudian dibagi menjadi 5 kelompok yaitu Kelompok PO (kontrol negatif) tanpa perlakuan, kelompok P1 dengan pemberian ekstrak daun beluntas 0.3 $\mathrm{mg} / 20 \mathrm{gBB}$, kelompok P2 dengan pemberian ekstrak daun beluntas 0.6 mg/20gBB, kelompok P3 dengan pemberian ekstrak daun bluntas 0.9 $\mathrm{mg} / 20 \mathrm{gBB}$, dan kelompok P4 (kontrol positif) dengan pemberian akarbose 0.13 $\mathrm{mg} / 20 \mathrm{gBB}$. Setelah pembagian kelompok dilakukan pengukuran kadar gluksoa dan kadar trigliserida darah pada mencit. Pengukuran ini dilakukan dengan menggunakan glukometer MultiCarein. Pengambilan sampel darah dilakukan dengan cara menggunting ekor mencit. Setelah pengukuran kadar glukosa, mencit kemudian diinduksi sukrosa 10\% secara ad libitum selama 20 hari. Pada hari ke 21 dilakukan pengukuran kadar glukosa mencit, kemudian mencit 
diberikan perlakuan terhadap mencit, sebelum diberikan perlakuan kadar glukosa mencit diukur kemudian mencit diberikan 5 perlakuan yang berbeda yaitu Penelitian ini menggunakan alat ukur kadar glukosa darah (MultiCarein) yang dipilih karena memiliki sensitivitas 94\% dan spesitifitas $98 \%$ dengan pengukuran kadar glukosa sebanyak 5 kali, sebelum induksi sukrosa, sebelum perlakuan $\left(\mathrm{t}_{0}\right)$, serta kadar glukosa pada menit ke 15 $\left(t_{1}\right)$, menit ke $30\left(t_{2}\right)$, dan menit ke $60\left(t_{3}\right)$.

\section{HASIL}

Pada ekstrak beluntas ditemukan adanya kandungan flavonoid, alkaloid, asam fenolat, tannin, monoterpene, seskuiterpen, polifenol, dan kuinon. Penentuan kadar secara kuantitatif dapat dilihat pada Tabel 1.

Data hasil penelitian pada Tabel 2 menunjukkan pada saat sebelum induksi sukrosa kadar glukosa sewaktu $M$. musculus menyatakan kisaran kadar glukosa normal. Setelah diinduksi sukrosa selama 20 hari dilakukan pengukuran kadar glukosa pada hari ke
21 atau sebelum perlakuan $\left(\mathrm{H}_{21+0^{\prime}}\right)$ didapatkan kadar glukosa $M$. musculus berkisar $>200 \mathrm{mg} / \mathrm{dl}$.

Data penelitian menunjukkan adanya efek yang berbeda pada 15 menit pertama setelah perlakuan di mana pada pengamatan didapatkan peningkatan kadar glukosa darah namun pemeriksaan berikutnya menunjukkan adanya penurunan kadar glukosa darah (Tabel 3, Gambar 1).

Pemberian sukrosa juga dapat meningkatkan kadar trigliserida darah (Tabel 4). Berdasarkan pengukuran kadar trigliserida pada menit ke-15, 30, dan 60 (Tabel 6, Gambar 2) didapatkan hasil pada kelompok kontrol negatif, pemberian ekstrak daun $P$. indica 0,3 $\mathrm{mg} / 20 \mathrm{gBB}$, dan kontrol postif dengan akarbose $0,13 \mathrm{mg} / 20 \mathrm{gBB}$ tidak terjadi penurunan kadar trigliserida, sedangkan pada kelompok pemberian ekstrak daun $P$. indica $0,6 \mathrm{mg} / 20 \mathrm{gBB}$ terjadi penurunan kadar trigliserida, namun penurunan tersebut tidak bermakna (Tabel 5).

Tabel 1. Hasil Uji Fitokimia Senyawa Metabolit Sekunder Daun Beluntas

\begin{tabular}{cc}
\hline Jenis Uji & Hasil Uji \\
\hline Flavonoid & + \\
Alkaloid & + \\
Asam fenolat & + \\
Tanin & ++ \\
Monoterpen & + \\
Seskuiterpen & ++ \\
Polifenol & + \\
Kuinon & +++ \\
\hline
\end{tabular}


Tabel 2. Hasil Uji T Berpasangan Sebelum dan Setelah Induksi Sukrosa

\begin{tabular}{|c|c|c|c|c|c|}
\hline Kadar glukosa (mg/dL) & $\mathrm{n}$ & Rerata (s.b) & Selisih (s.b) & IK95\% & Nilai $p$ \\
\hline Sebelum diabetes $\left(\mathrm{H}_{0}\right)$ & 25 & $126,68(21.36)$ & $128,32(27.50)$ & $116,9-139,6$ & 0,000 \\
\hline Setelah diabetes $\left(\mathrm{H}_{21}\right)$ & 25 & $255,00(16.42)$ & & & \\
\hline
\end{tabular}

Tabel 3. Rata-Rata Kadar Glukosa Sebelum Perlakuan, Menit ke-15, 30, dan 60 Setelah Perlakuan.

\begin{tabular}{|c|c|c|c|c|c|}
\hline \multirow{2}{*}{ Kelompok } & \multirow{2}{*}{$\mathbf{N}$} & \multicolumn{4}{|c|}{ Kadar Glukosa (mg/dL) } \\
\hline & & $\mathbf{H}_{21+0}$ & $\mathrm{H}_{21+15^{\prime}}$ & $\mathrm{H}_{21+30^{\prime}}$ & $\mathrm{H}_{21+60^{\prime}}$ \\
\hline Kontrol negatif & 5 & $253,2 \pm 14,923$ & $\begin{array}{l}269,4 \pm 26,63 \\
3\end{array}$ & $\begin{array}{l}275,0 \pm 34,91 \\
4\end{array}$ & $266,2 \pm 36,820$ \\
\hline $\begin{array}{l}\text { Kontrol positif dengan } \\
\text { pemberian } \\
\text { akarbose } 0,13 \\
\text { mg/20Gbb }\end{array}$ & 5 & $253,4 \pm 20,756$ & $\begin{array}{l}259,2 \pm 29,04 \\
7\end{array}$ & $\begin{array}{l}231,8 \pm 31,42 \\
8\end{array}$ & $222,4 \pm 22,356$ \\
\hline $\begin{array}{l}\text { Pemberian ekstrak } \\
\text { metanol daun } P \text {. } \\
\text { indica } 0,3 \mathrm{mg} / 20 \mathrm{gBB}\end{array}$ & 5 & $252,0 \pm 20,869$ & $\begin{array}{l}267,4 \pm 23,42 \\
8\end{array}$ & $\begin{array}{l}243,0 \pm 24,42 \\
3\end{array}$ & $230,4 \pm 11,866$ \\
\hline $\begin{array}{l}\text { Pemberian ekstrak } \\
\text { metanol daun } P \text {. } \\
\text { Indica } 0,6 \mathrm{mg} / 20 \mathrm{gBB}\end{array}$ & 5 & $254,4 \pm 13,939$ & $\begin{array}{l}261,2 \pm 12,31 \\
7\end{array}$ & $\begin{array}{l}232,2 \pm 15,65 \\
9\end{array}$ & $214,4 \pm 15,126$ \\
\hline $\begin{array}{l}\text { Pemberian ekstrak } \\
\text { metanol daun } P \text {. } \\
\text { Indica } 0,9 \mathrm{mg} / 20 \mathrm{gBB}\end{array}$ & 5 & $262,0 \pm 16,000$ & $\begin{array}{l}247,2 \pm 12,02 \\
9\end{array}$ & $\begin{array}{l}203,8 \pm 10,37 \\
8\end{array}$ & $191,0 \pm 25,564$ \\
\hline
\end{tabular}

Tabel 4. Hasil Uji T Berpasangan Kadar Trigliserida Sebelum dan Setelah Diabetes

\begin{tabular}{|c|c|c|c|c|}
\hline Kadar trigliserida (mg/dL) & Rerata \pm s.b. & Rerata \pm s.b. & $\mathrm{IK} 95 \%$ & Nilai $p$ \\
\hline Sebelum diabetes $(n=25)$ & $135,36 \pm 2, .28$ & $104,8 \pm 17.3$ & $97,3-111,6$ & 0,000 \\
\hline Setelah diabetes $(n=25)$ & $239,84 \pm 24,18$ & & & \\
\hline
\end{tabular}




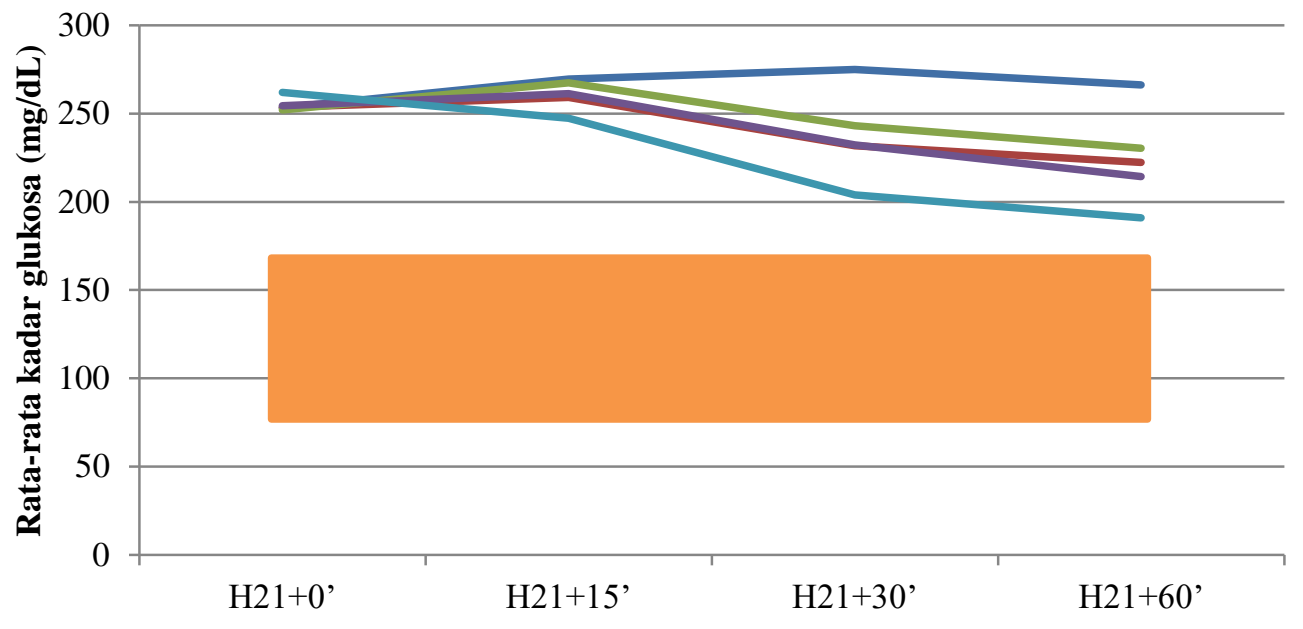

Waktu pengukuran kadar glukosa

$\longrightarrow \mathrm{P} 0-\mathrm{P} 1-\mathrm{P} 2-\mathrm{P} 3-\mathrm{P} 4 \square$ Glukosa Normal

Gambar 1. Rata-Rata Kadar Glukosa Darah M. musculus Sebelum Dan Setelah Perlakuan.

Keterangan : $\mathrm{H}_{21+0^{\prime}}=$ Pengukuran kadar glukosa sebelum perlakuan pada hari ke 21 setelah induksi sukrosa; $\mathrm{H}_{21+15^{\prime}}$ = Pengukuran kadar glukosa menit ke 15 setelah perlakuan pada hari ke 21 setelah induksi sukrosa; $\mathrm{H}_{21+30^{\prime}}=$ Pengukuran kadar glukosa menit ke 30 setelah perlakuan pada hari ke 21 setelah induksi sukrosa; $\mathrm{H}_{21+60^{\prime}}=$ Pengukuran kadar glukosa menit ke 60 setelah perlakuan pada hari ke 21 setelah induksi sukrosa; $\mathrm{P} 0=$ kontrol negatif; $\mathrm{P} 1=$ pemberian akarbose dengan dosis $0,13 \mathrm{mg} / 20 \mathrm{~g} \mathrm{BB}$ per hari; $\mathrm{P} 2=$ pemberian ekstrak metanol daun $P$. indica dengan dosis $0,3 \mathrm{mg} / 20 \mathrm{gBB}$; $\mathrm{P} 3=$ pemberian ekstrak methanol daun $P$. indica dengan dosis $0,6 \mathrm{mg} / 20 \mathrm{gBB}$; $\mathrm{P} 4=$ pemberian ekstrak methanol daun $P$. indica dengan dosis $0,9 \mathrm{mg} / 20 \mathrm{gBB}$.

Tabel 5. Hasil Analisis Korelasi Pearson Kadar Glukosa dan Kadar Trigliserida M. musculus

\begin{tabular}{cccccc}
\hline & $\mathrm{n}$ & Kadar Trigliserida $(\mathrm{mg} / \mathrm{dL})$ & Kadar Glukosa $(\mathrm{mg} / \mathrm{dL})$ & $\mathrm{r}$ & $\mathrm{P}$ \\
\hline Sebelum Diabetes & 25 & $135,36 \pm 22,28$ & $126,68 \pm 21,36$ & 0,099 & 0,638 \\
Setelah Diabetes & 25 & $239,84 \pm 24,18$ & $255,00 \pm 16,42$ & 0,102 & 0,627 \\
$\begin{array}{c}\text { Sebelum dan Setelah } \\
\text { Diabetes }\end{array}$ & 50 & $190,84 \pm 9,54$ & $187,60 \pm 8,14$ & 0,891 & 0,000 \\
\hline
\end{tabular}

Keterangan : $\mathrm{n}=$ jumlah sample; $r=$ koefisien korelasi 
Tabel 6. Rata-Rata Kadar Trigliserida Sebelum Perlakuan, Menit ke 15, 30 dan 60 Setelah Perlakuan.

\begin{tabular}{|c|c|c|c|c|c|}
\hline \multirow{2}{*}{ Kelompok } & \multirow{2}{*}{$\mathbf{N}$} & \multicolumn{4}{|c|}{ Kadar Trigliserida (Mg/DI) } \\
\hline & & $\mathrm{H}_{21+0}$ & $H_{21+15}$ & $\mathrm{H}_{21+30^{\prime}}$ & $\mathrm{H}_{21+60^{\prime}}$ \\
\hline Kontrol negatif & 5 & $240,8 \pm 36,755$ & $245,0 \pm 32,992$ & $248,2 \pm 31,035$ & $240,8 \pm 29,920$ \\
\hline $\begin{array}{l}\text { Kontrol positif dengan } \\
\text { pemberian akarbose } \\
0,13 \mathrm{mg} / 20 \mathrm{gBB}\end{array}$ & 5 & $236,6 \pm 33,231$ & $229,4 \pm 18,929$ & $234,2 \pm 23,004$ & $236,0 \pm 24,920$ \\
\hline $\begin{array}{l}\text { Pemberian ekstrak metanol } \\
\text { daun P. indica } 0,3 \mathrm{mg} / 20 \mathrm{gBB}\end{array}$ & 5 & $232,6 \pm 20,501$ & $228,2 \pm 17,021$ & $217,2 \pm 28,102$ & $228,8 \pm 20,450$ \\
\hline $\begin{array}{l}\text { Pemberian ekstrak metanol } \\
\text { daun } P \text {. indica } 0,6 \mathrm{mg} / 20 \mathrm{gBB}\end{array}$ & 5 & $243,3 \pm 20,768$ & $230,8 \pm 9.808$ & $224,6 \pm 15,241$ & $225,4 \pm 20,501$ \\
\hline $\begin{array}{l}\text { Pemberian ekstrak metanol } \\
\text { daun P. indica } 0,9 \mathrm{mg} / 20 \mathrm{gBB}\end{array}$ & 5 & $245,8 \pm 7,791$ & $244,8 \pm 9,088$ & $228,8 \pm 17,021$ & $212,2 \pm 12,602$ \\
\hline
\end{tabular}

Keterangan : $\mathrm{H}_{21+0^{\prime}}=$ Pengukuran kadar trigliserida sebelum perlakuan pada hari ke 21 setelah induksi sukrosa, $\mathrm{H}_{21+15^{\prime}}=$ Pengukuran kadar trigliserida menit ke 15 setelah perlakuan pada hari ke 21 setelah induksi sukrosa, $\mathrm{H}_{21+30}$ = Pengukuran kadar trigliserida menit ke 30 setelah perlakuan pada hari ke 21 setelah induksi sukrosa, $\mathrm{H}_{21+60}=$ Pengukuran kadar trigliserida menit ke 60 setelah perlakuan pada hari ke 21 setelah induksi sukrosa.

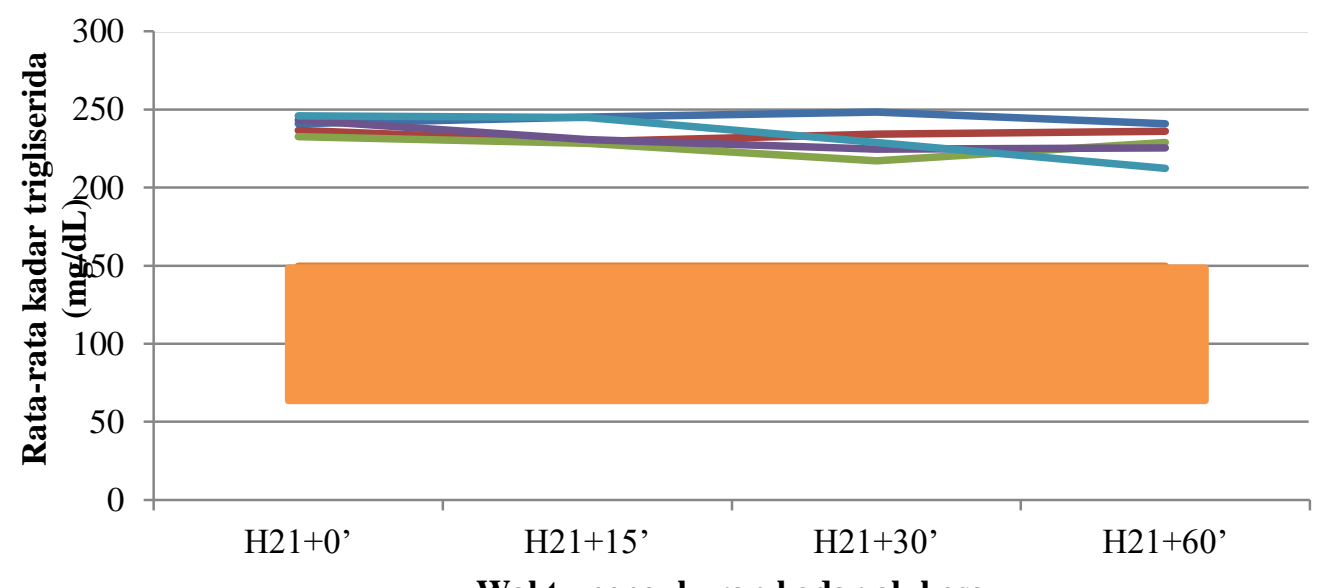

Waktu pengukuran kadar glukosa

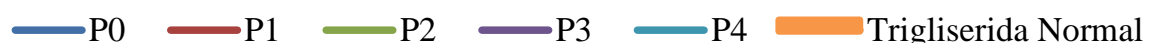

Gambar 2. Rata-rata kadar trigliserida darah M. musculus sebelum dan setelah perlakuan

Keterangan : $\mathrm{H}_{21+0^{\prime}}=$ Kadar trigliserida sebelum perlakuan pada hari ke 21 setelah induksi sukrosa; $\mathrm{H}_{21+15^{\prime}}=\mathrm{Kadar}$ trigliserida menit ke 15 setelah perlakuan pada hari ke 21 setelah induksi sukrosa; $\mathrm{H}_{21+30}$ = Kadar trigliserida menit ke 30 setelah perlakuan pada hari ke 21 setelah induksi sukrosa; $\mathrm{H}_{21+60}$ = Kadar trigliserida menit ke 60 setelah perlakuan pada hari ke 21 setelah induksi sukrosa; $\mathrm{P0}=$ kontrol negatif; $\mathrm{P} 1$ = pemberian akarbose $0,13 \mathrm{mg} / 20 \mathrm{~g} \mathrm{BB}$; P2 = pemberian ekstrak metanol daun $P$. indica dengan dosis $0,3 \mathrm{mg} / 20 \mathrm{gBB}$; P3 = pemberian ekstrak methanol daun $P$. indica dengan dosis $0,6 \mathrm{mg} / 20 \mathrm{gBB} ; \mathrm{P} 4=$ pemberian ekstrak metanol daun $P$. indica dengan dosis 0,9 $\mathrm{mg} / 20 \mathrm{gBB}$. 


\section{PEMBAHASAN}

Pada uji efek pemberian ekstrak metanol daun $P$. indica terhadap kadar glukosa darah, M. musculus terlebih dahulu diinduksi dengan menggunakan larutan sukrosa $10 \%$. Pemberian sukrosa dilakukan karena diet tinggi sukrosa dapat memicu terjadinya obesitas dan diabetes melitus tipe $2 .{ }^{11}$ dan juga menyebabkan gangguan kerja insulin melalui efek sukrosa pada hepar. ${ }^{12}$ Pemberian pakan normal dan penambahan sukrosa ke dalam air minum sebagai sumber kalori ekstra telah terbukti dapat meyebabkan terjadinya obesitas, hipertensi, hiperlipidemia, dan hiperinsulinemia. ${ }^{13}$ Diet tinggi sukrosa tidak menyebabkan kegemukan pada M. musculus, tetapi memiiki potensi hipertrofi asiposit, intoleransi glukosa, hiperinsulinemia, hiperlipidemia, steatosis hepatic dan peningkatan kadar sitokin. ${ }^{14}$ Sebelum pemberian sukrosa dilakukan pengukuran kadar glukosa darah awal. Kadar glukosa selanjutnya diukur kembali pada hari ke 10 setelah induksi sukrosa untuk menilai apakah $M$. musculus telah mengalami diabetes, berdasarkan hasil pengukuran kadar glukosa didapatkan kadar glukosa $M$. musculus yang menandakan $M$. musculus belum mengalami diabetes, di mana kadar glukosa normal pada $M$. musculus jantan galur Swiss Webster berkisar $112 \pm 38.1 \mathrm{mg} / \mathrm{dL}^{15}$. Berdasarkan hal tersebut induksi sukrosa dilanjutkan hingga hari ke 20. Pada hari ke 21 dilakukan pengukuran kadar glukosa $M$. musculus, kemudian M. musculus diberikan perlakuan terhadap $M$. musculus, sebelum diberikan perlakuan kadar glukosa M. musculus diukur kemudian $M$. musculus diberikan 5 perlakuan yang berbeda yaitu kelompok kontrol negatif yaitu kelompok tanpa perlakuan, kelompok kontrol positif yaitu kelompok dengan pemberian akarbose $0.13 \mathrm{mg} / 20 \mathrm{gBB}$, kelompok dengan pemberian ekstrak daun $P$. indica 0.3 $\mathrm{mg} / 20 \mathrm{gBB}$, kelompok dengan pemberian ekstrak daun $P$. indica $0.6 \mathrm{mg} / 20 \mathrm{gBB}$, kelompok dengan pemberian ekstrak daun bluntas $0.9 \mathrm{mg} / 20 \mathrm{gBB}$, dan Penelitian ini menggunakan alat ukur kadar glukosa darah (MultiCarein) yang dipilih karena memiliki sensitivitas $94 \%$ dan spesitifitas $98 \%$ dengan pengukuran kadar glukosa sebanyak 5 kali, sebelum induksi sukrosa, sebelum perlakuan $\left(\mathrm{H}_{21+0^{\prime}}\right)$, serta kadar glukosa pada menit ke $15\left(\mathrm{H}_{21+15^{\prime}}\right)$, menit ke $30\left(\mathrm{H}_{21+30^{\prime}}\right)$, dan menit ke $60\left(\mathrm{H}_{21+60^{\circ}}\right)$.

Berdasarkan data hasil penelitian dapat dilihat pada saat sebelum induksi sukrosa kadar glukosa sewaktu M. musculus menyatakan kisaran kadar glukosa normal. Setelah diinduksi sukrosa selama 20 hari dilakukan pengukuran kadar glukosa pada hari ke 21 atau sebelum perlakuan $\left(\mathrm{H}_{21+0}\right)$ didapatkan kadar glukosa $M$. musculus berkisar $>200 \mathrm{mg} / \mathrm{dl}$ yang menunjukkan bahwa semua $M$. musculus telah mengalami diabetes. Hal ini disebabkan karena terjadinya penyerapan glukosa dalam tubuh sehingga glukosa masuk ke dalam darah yang disebabkan sel B tidak dapat bekerja optimal karena glukosa yang dikonsumsi berlebihan dan menyebabkan keadaan hiperglikemik pada $M$. musculus yang merupakan pertanda terjadinya diabetes ${ }^{16}$.

Data penelitian menunjukkan adanya efek yang berbeda pada 15 menit pertama setelah perlakuan di mana pada pengamatan didapatkan peningkatan kadar glukosa darah pada kelompok kontrol negatif yaitu kelompok 
Jurnal Kedokteran Raflesia, Volume 3, Nomor 1 Juni 2017

tanpa perlakuan, kelompok kontrol positif, kelompok dengan pemberian ekstrak daun $P$. indica $0.3 \mathrm{mg} / 20 \mathrm{gBB}$, dan kelompok dengan pemberian ekstrak daun $P$. indica $0.6 \mathrm{mg} / 20 \mathrm{gBB}$ M. musculus. Hal ini kemungkinan disebabkan masih bekerjanya penyerapan glukosa dalam darah sehingga kadar glukosa darah $M$. musculus terus meningkat. Akan tetapi peningkatan ini secara statistik tidak signifikan $(p$ >0.05). Pada kelompok kontrol negatif peningkatan kadar glukosa ini terus terjadi hingga menit ke 60 , meskipun pada menit ke 30 hingga 60 terjadi penurunan yang tidak signifikan di mana kadar glukosa pada menit ke 60 masih lebih tinggi jika dibandingkan glukosa sebelum perlakuan. Pada kelompok kontrol positif, penurunan kadar glukosa terjadi pada pengamatan 30 menit setelah pemberian akarbose hingga 60 menit setelah pemberian akarbose. Pemberian akarbose dengan dosis $0.13 \mathrm{mg} / \mathrm{dl}$ memiliki efek penuruanan kadar glukosa dara M. musculus. Hal ini sejalan dengan kinerja akarbose yang dapat menghambat enzim alfa glukosidase. Akarbose bekerja dengan mengurangi absorpsi glukosa di usus halus, sehingga mempunyai efek menurunkan kadar glukosa darah sesudah makan $^{17}$. Kadar glukosa darah dengan pemberian ekstrak daun $P$. indica 0,3 $\mathrm{mg} / 20 \mathrm{gBB}$, pemberian ekstrak daun $P$. indica $0,6 \mathrm{mg} / 20 \mathrm{gBB}$, dan pemberian ekstrak daun $P$. indica $0,9 \mathrm{mg} / 20 \mathrm{gBB}$ mengalami penurunan, di mana penurunan kadar glukosa ini terjadi sejak 30 menit setelah pemberian ekstrak pada kelompok pemberian ekstrak daun $P$. indica 0,3 $\mathrm{mg} / 20 \mathrm{gBB}$ dan pemberian ekstrak daun $P$. indica $0,6 \mathrm{mg} / 20 \mathrm{gBB}$, sedangkan pada kelompok pemberian ekstrak daun $P$. indica 0,9 $\mathrm{mg} / 20 \mathrm{gBB}$ telah dimulai sejak 15 menit setelah pemberian ekstrak. Penurunan kadar glukosa pada ketiga kelompok pemberian ekstrak metanol daun beluntas ini terus terjadi hingga menit ke 60 setelah pemberian ekstrak. Penurunan kadar glukosa darah pada pemberian ekstrak daun $P$. indica disebabkan oleh mekanisme penghambatan enzim alfaglukosidase yaitu enzim di dalam usus yang mengubah disakarida menjadi glukosa. Inhibitor enzim alfa glukosidase ini menghambat absorpsi glukosa pada usus halus sehingga berfunsi sebagai agen antihiperglikemik ${ }^{18}$. Penurunan kadar glukosa ini juga kemungkinan terjadi melalui kerja tanin. Tanin diketahui bersifat astringen yang dapat mempresipitasikan protein selaput lendir di usus dan membentuk lapisan yang melindungi usus, sehingga menghambat penyerapan glukosa. Selain itu tanin juga dapat memperbaiki stress oksidatif patologik pada kondisi diabetes serta tanin juga bertindak sebagai anti radikal bebas dan mengaktifkan enzim antioksidan yang meregenerasi sel pankreas. ${ }^{19}$ Flavonoid yang terkandung dalam ekstrak daun $P$. indica juga diduga berperan dalam penurunan kadar glukosa darah $M$. musculus dikarenakan kinerja flavonoid yang dapat meningkatkan ambilan glukosa dijaringan perifer dan menghambat glukoneogenesis. Selain itu, flavonoid sebagai antioksidan secara tidak langsung juga mendukung efek anti inflamasi. Flavonoid dapat mencegah komplikasi atau progresifitas diabetes dengan cara membersihkan radikal bebas yang berlebihan, memutuskan rantai reaksi radikal bebas. Radikal bebas dapat menarik berbagai mediator 
Jurnal Kedokteran Raflesia, Volume 3, Nomor 1 Juni 2017

inflamasi, flavonoid dapat menstabilkan Reactive Oxygen Species (ROS) dengan bereaksi dengan senyawa reaktif dari radikal sehingga radikal menjadi inaktif. ${ }^{20}$ Pada penelitian ini didapatkan hasil penurunan kadar glukosa paling signifikan terjadi pada kelompok dengan pemberian ekstrak daun $P$. indica $0.9 \mathrm{mg} / \mathrm{dL}$, hal ini kemungkinan disebabkan karena pada konsentrasi kecil, senyawa-senyawa yang terdapat dalam ekstrak daun belunas memiliki pengaruh yang lebih sedikit dan kerja yang lebih lama dalam menurunkan kadar glukosa, sedangkan pada konsentrasi besar memiliki pengaruh yang lebih banyak dan kerja yang lebih cepat dalam menurunkan kadar glukosa. Hal ini terlihat pada hasil di mana pada kelompok pemberian ekstrak daun $P$. indica 0,3 $\mathrm{mg} / 20 \mathrm{gBB}$ dan 0,6 mg/20gBB penurunan kadar glukosa baru terjadi pada menit ke 30 dengan rata-rata penurunan kadar glukosa pada kelompok pemberian ekstrak daun $P$. indica 0,3 $\mathrm{mg} / 20 \mathrm{gBB}$ sebesar $7.9 \%$ dan pada kelompok pemberian ekstrak daun $P$. indica $0,6 \mathrm{mg} / 20 \mathrm{gBB}$ sebesar $18.65 \%$ setelah 60 menit pemberian ekstrak, sedangkan pada kelompok pemberian ekstrak daun $P$. indica $0,9 \quad \mathrm{mg} / 20 \mathrm{gBB}$ penurunan kadar glukosa telah dimulai sejak menit ke 15 setelah pemberian ekstrak dengan rata-rata penurunan kadar glukosa mencapai $37.17 \%$ pada menit ke 60 setelah pemberian ekstrak. Berdasarkan hal ini dapat dinyatakan bahwa semakin tinggi konsentrasi ekstrak maka semakin baik pula kerja ekstrak dalam menurunkan kadar glukosa.

Penelitian ini juga menilai peningkatan kadar trigliserida akibat dari keadaan diabetes yang dialami oleh $M$. musculus setelah induksi sukrosa selama 20 hari. Pengukuran kadar trigliserida dilakukan sebelum induksi sukrosa, sebelum pemberian ekstrak pada hari ke 21, dan pada menit ke 15, 30, dan 60 setelah pemberian ekstrak. Berdasarkan perbandingan kadar trigliserida sebelum dan setelah induksi sukrosa terjadi peningkatan kadar trigliserida setelah 20 hari induksi sukrosa. Peningkatan ini menujukkan bahwa $M$. musculus mengalami hipertrigliseridemia di mana kadar trigliserida normal berkisar $91 \pm 58,5 \mathrm{mg} / \mathrm{DI} .{ }^{15}$ Berdasarkan uji t berpasangan peningkatan kadar trigliserida ini signifikan dengan nilai $p<0.05(p=0.000)$. Peningkatan kadar trigliserida ini kemungkinan disebabkan karena kadar glukosa darah yang tinggi dapat mempercepat pembentukan trigliserida dalam hati karena pada keadaan kadar glukosa yang tinggi terjadi perangsangan pembentukan glikogen dari glukosa, sintesis asam lemak, dan kolesterol dari glukosa. ${ }^{4}$ Selain itu, pada kondisi diabetes terjadi gangguan sekresi insulin yang merupakan salah satu hormon yang mempengaruhi kadar trigliserida di mana hormon insulin dapat menurunkan kadar trigliserida darah, karena insulin dapat mencegah hidrolisis trigliserida. Pada keadaan berkurangnya insulin, enzim lipoprotein lipase tidak dapat bekerja optimal. Enzim lipoprotein lipase ini merupakan enzim yang berperan dalam menurunkan kadar trigliserida, sehingga dengan adanya gangguan insulin, hidrolisis trigliserida cenderung meningkat dan menyebabkan meningkatkan kadar trigliserida. ${ }^{21}$ Untuk menilai hubungan peningkatan kadar trigliserida dengan kadar glukosa dilakukan uji korelasi pearson pada saat sebelum induksi sukrosa setelah induksi 
Jurnal Kedokteran Raflesia, Volume 3, Nomor 1 Juni 2017

sukrosa, serta sebelum dan setelah induksi sukrosa. Berdasarkan hasil didapatkan hubungan korelasi pearson sebesar 0,099 pada saat sebelum dan 0,102 pada saat setelah induksi menunjukkan korelasi positif dengan kekuatan korelasi yang sangat lemah dan secara keseluruhan tidak adanya korelasi antara peningkatan kadar trigliserida dan kadar glukosa, hal ini dinyatakan dengan nilai $p>0.05$. Akan tetapi pada uji korelasi kadar trigliserida sebelum dan setelah perlakuan didapatkan korelasi pearson 0,891 yang menunjukkan korelasi positif dengan kekuatan korelasi yang kuat, dan secara keseluruhan terdapat korelasi antara peningkatan kadar trigliserida dan kadar glukosa, hal ini dinyatakan dengan nilai $p<0.05$ $(p=0,000)$.

Penilaian efek pemberian ekstrak daun $P$. indica terhadap kadar trigliserida darah $M$. musculus juga dilakukan dengan melakukan pengukuran sebelum perlakuan dan menit ke-15, 30, dan 60 setelah perlakuan. Berdasarkan pengukuran tersebut didapatkan hasil pada kelompok kontrol negatif, pemberian ekstrak daun $P$. indica $0,3 \mathrm{mg} / 20 \mathrm{gBB}$, dan kontrol postif dengan akarbose $0,13 \mathrm{mg} / 20 \mathrm{gBB}$ tidak terjadi penurunan kadar trigliserida, sedangkan pada kelompok pemberian ekstrak daun $P$. indica 0,6 $\mathrm{mg} / 20 \mathrm{gBB}$ terjadi penurunan kadar trigliserida sebesar $7.94 \%$ setelah 60 menit pemberian ekstrak akan tetapi penurunan kadar trigliserida ini tidak bermakna secara statistik. Pada kelompok pemberian ekstrak daun $P$. indica 0,9 $\mathrm{mg} / 20 \mathrm{gBB}$ terjadi penurunan kadar trigliserida sebesar $15.83 \%$ pada menit ke 60 setelah pemberian ekstrak dan penurunan ini secara statistik bermakna yang dinyatakan dengan nilai $p<0.05$. Penurunan kadar trigliserida ini kemungkinan disebabkan karena kandungan tanin pada ekstrak daun $P$. indica. Tanin memiliki efek inhibisi terhadap enzim lipase pankreas di mana enzim ini berperan dalam menghidrolisis 1,3-triasilgliserol menjadi 2-monoasilgliserol dan asam lemak bebas. ${ }^{22}$

Senyawa lain yang diduga berperan dalam menurunkan kadar trigliserida pada penelitian ini adalah flavonoid yang dapat menghambat enzim HMG-KoA reduktase sehingga dapat menurunkan kadar trigliserida dalam darah. ${ }^{23}$ Flavonoid juga dapat menurunkan kadar trigliserida dengan meningkatkan aktivitas enzim lipoprotein lipase yang berperan dalam proses hidrolisis trigliserida menjadi asam lemak bebas. Selain itu, penurunan kadar trigliserida juga dapat disebabkan karena adanya saponin di dalam ekstrak daun $P$. indica yang mengikat lemak yang terdapat dalam lumen usus dan membentuk senyawa kompleks tidak larut dan tidak dapat diserap oleh mukosa usus. Selain itu saponin juga dapat meningkatan produksi dan sekresi empedu dan juga melancarkan metabolisme lemak sehingga dapat menurunkan kadar trigliserida darah. ${ }^{24}$

\section{UCAPAN TERIMA KASIH}

Dalam penyusunan naskah publikasi ini, penulis mendapat bantuan dari berbagai pihak, untuk itu penulis mengucapkan terima kasih kepada Sumber Belajar IImu Hayati (SBIH) yang telah menyediakan sarana dan prasarana yang membantu penelitian ini sehingga dapat berjalan dengan baik. 
Jurnal Kedokteran Raflesia, Volume 3, Nomor 1 Juni 2017

\section{DAFTAR PUSTAKA}

1. American Diabetes Association. Diagnosis and classification of diabetes melitus. Diabetes care; 2010.

2. International Diabetes Federation. IDF Diabetes Atlas seventh edition; 2015.

3. Badan Penelitian dan Pengembangan Kesehatan RI. Riset Kesehatan Dasar; RISKESDAS. Jakarta: Balitbang Kemenkes RI; 2013.

4. Koestadi. Kimia Klinik Teori dan Praktek Darah. Kediri: AAK Bhakti Wiyata; 1989.

5. Price SA and Wilson LM. Patofisiologi: Konsep Klinis Proses-Proses Penyakit Edisi. Jakarta: EGC; 2006.

6. Bello A, Aliero AA, Saidu Y, Muhammad $S$. Phytochemical screening, polyphenolic content and alpha-glucosidase inhibitory potential of Leptadeniahastata (Pers.) Decne. Nigerian Journal of Basic and Applied Science 2012; 19(2): 181-186.

7. Arsiningtyas IS, Gunawan P, Kato E, Kawabata J. Identification of alphaglucosidase inhibitors from the leaves of Pluchea indica (L.) Less., a traditional Indonesian herb: Promotion of natural product use; 2014.
8. Bosenberg LH. The mechanism of action of oral antidiabetic drugs: a review of recent literature. The journal of endocrinology, Metabolism and Diabetes of South Africa 2008; 13(3). pp. 80-88.

9. Trathip A. Phytochemistry and antioxidant activity of Pluchea indica. [unpublished thesis]. Bangkok: Mahidol University; 2005.

10. Andarwulan N, Batari R, Sandrasari DA. Flavonoid content and antioxidant activity of vegetables from Indonesia. Food Chem 2012; 0;121:1231-1235. doi: 10.1016/j.foodchem.2010.01.033.

11. Walker CG, Zariwala MG, Holness MJ, Sugden MC. Diet, obesity and diabetes: a current update. Clin. Sci. (Lond.) 2007; 112(2):93-111.

12. Storlien LH, Kraegen EW, Jenkins $A B$, Chisholm DJ. Effects of sucrose vs starch diets on in vivo insulin action, thermogenesis, and obesity in rats. Am. J. Clin. Nutr 1988; 47(3):420-7.

13. Oliart Ros, Torres Marquez ME, Badillo A, Angulo Guerrero. Dietary fatty acids effects on sucrose-induced cardiovascular syndrome in rats. J. Nutr. Biochem. 2001;12(4):207-12. 
Jurnal Kedokteran Raflesia, Volume 3, Nomor 1 Juni 2017

14. Oliveira L, Santos D, Barbosa-da-Silva S, Mandarim-de-Lacerda C, Aguila M. The inflammatory profile and liver damage of a sucrose-rich diet in mice. J. Nut. Biochem 2014;25(2):193-200.

15. Marcel I dan Perret Gentil. Mouse Biomethodology. University Veterinarian \& Director Laboratory Animal Resources Center : The University of Texas at San Antonio; 2015.

16. Takihata $M$, Nakamura A, Tajima $K$, Komatsu Y, Tamura H, Yamazaki S, Kondo Y, Yamada M, Kimura, M, Terauchi, Y. Comparative study of sitagliptin with pioglitazone in Japanese type 2 diabetic patients: the COMPASS randomized controlled trial. Diabetes Obes. Metab 2013;15(5): 455-62,

17. PERKENI. Konsensus pengelolaan dan pencegahan diabetes melitus tipe 2 di Indonesia; 2011.

18. Widyawati S Paini, Budianta TDW, Gunawan DI, Wongso RS. Evaluation antidiabetic activity of various leaf extracts of pluchea indica less. IJPPR 2015;7(3), pp. 597-603.
19. Sudjaroen $Y, R$ Hauoner, Wurtele G, Hull WE, Erben, Spiegelhalder, Chang $S$, Bartsch, Owen, RW. Isolation and Structure Elucidation of Phenolic Antioksidants from Tamarind (Tamarindus indica L) Seed and Pericarp. Food and Chemical Toxicology Elsevier 2005;43(11) : 1673-1682

20. Ahmed J, Ramaswamy HS, Sashidhark C. Rheological Characteristics of Tamarind (Tamarindus indica L) Juice Concentrates. Swiss Society of Food Science and Technology Elsevier; 2005; 40:225-6

21. Guyton AC, Hall JE. 2007. Buku Ajar Fisiologi Kedokteran. Edisi 11. Jakarta: EGC; 2007.

22. Silitonga RF. Daya Inhibisi Ekstrak Daun Jati Belanda dan Bangle Terhadap Aktivitas Lipase Pankreas Sebagai Antiobesitas, Skripsi, Fakultas Matematika dan IImu Pengetahuan Alam, Institut Pertanian Bogor; 2008. 
23. Fithriani NA, Pudjadi, Kartikawati $H$. Pengaruh Pemberian Ekstrak Bawang Merah (Allium ascalonicum) Terhadap Kadar Trigliserida Serum Tikus Wistar Hiperlipidemia. Fakultas Kedokteran Universitas Diponegoro; 2010.

24. Marrelli M, Conforti F, Araniti F, Giancarlo A. Effects of Saponins on Lipid Metabolism: A Review of Potential Health Benefits in the Treatment of Obesity. Molecules 2016. [Online] Available at: file://C:/Users/user/Downloads/molecules21-01404.pdf 